\title{
Effect of solvent type and number of coating layers on the contact angle of hydrophilic TiO2 thin film
}

\author{
Atilla Evcin ${ }^{1, a)}$ and Emine Yaşar ${ }^{2, b}$ \\ ${ }^{1}$ Afyon Kocatepe University, Materials Science and Engineering Department, 03200, Afyonkarahisar, Turkey ${ }^{2}$ Afyon Kocatepe \\ University, Biomedical Engineering Department, 03200, Afyonkarahisar, Turkey \\ ${ }^{a)}$ Corresponding author: evcin@aku.edu.tr orcid id: 0000-0002-0163-5097 \\ b) emineyasar21@, hotmail.com orcid id:0000-0002-7234-2259
}

(Received date: 24.12 .2021 and Accepted date: 30.12 .2021 )

(DOI: 10.29228/JCHAR.55618)

REFERENCES: Evcin A., Yaşar E., Effect of solvent type and number of coating layers on the contact angle of hydrophilic TiO2 thin film. Journal of Characterization, (1), Special Issue, 18-28, 2021.

\begin{abstract}
In this study, titanium isopropoxide was chosen as a precursor. It was dissolved in isopropanol for 30 minutes. Then non-ionic surfactants (Triton X-100), were used to obtain the separation and mono dispersion in the sol-gel reaction. In this experiment, the dip-coating method was chosen as a coating method. Sodalime glass substrates were coated with the alkoxide-based coating solution by a dip coater. The coated films were dried at $80^{\circ} \mathrm{C}$ in an oven to allow the alcohol, organic solvent, and excess water to evaporate from the films. After evaporation of solvents, coated glasses were characterized by scanning electron microscopy (SEM), goniometer, light Transmittance/Haze meter, and Gloss meter. The hydrophilic surface was successfully obtained from titanium alkoxide-based coating solution.
\end{abstract}

Keywords: sol-gel method, alkoxide, hydrophilic, thin film

\section{Çözücü tipinin ve kaplama tabakası sayısının hidrofilik $\mathrm{TiO}_{2}$ ince filmin temas açısına etkisi}

$\ddot{O} z$

$\mathrm{Bu}$ çalışmada, başlangıç kimyasalı olarak titanyum izopropoksit seçildi. İzopropanol içinde 30 dakika çözündürüldü. Daha sonra sol-jel reaksiyonunda ayırma ve mono dispersiyon elde etmek için iyonik olmayan yüzey aktif maddeler (Triton X-100) kullanıldı. Bu deneyde, kaplama yöntemi olarak daldırma kaplama yöntemi seçilmiştir. Soda-kireç cam substratlar, bir daldırma kaplayıcı ile alkoksit bazlı kaplama çözeltisi ile kaplandı. Kaplanmış filmler, alkolün, organik çözücünün ve fazla suyun filmlerden buharlaşmasına izin vermek için bir firında $80^{\circ} \mathrm{C}$ 'de kurutuldu. Çözücülerin buharlaştırılmasından sonra, kaplanmış camlar taramalı elektron mikroskobu (SEM), gonyometre, ışı Geçirgenliği/Buğu ölçer ve Parlaklık ölçer ile karakterize edildi. Hidrofilik yüzey, titanyum alkoksit bazlı kaplama çözeltisinden başarıyla elde edildi.

Anahtar Kelimeler: sol-jel yöntemi, alkoksit, hidrofilik, ince film 


\section{Introduction}

Recently, with the advancement of technology, materials are needed to show more performance and expectations are increasing. New production methods have been developed in line with these expectations and needs. The sol-gel method is also one of the developed methods.

The sol-gel method is the process of transition of sol composition from a liquid sol phase to a solid gel phase using pre-initiators (metal salts and metal alkoxides), solvents, and catalysts [1]. Sol-gel technology can be applied in many different fields such as glass and ceramic industry [2], chemical sensors, nuclear studies, space technology, production of more useful and more efficient materials for electronic devices.[3]. Coating glass, ceramic, metal, polymeric surfaces with the sol-gel method provides the improvement of many surface properties of the material [4,5]. With the surface modifications made in this way, surface properties of materials such as roughness, surface energy, surface charge, hydrophilicity, compatibility, and usability are improved [6]. The sol-gel method provides advantages such as low application temperature, wide usage area, easy accessibility of the materials to be used.

The sol-gel immersion technique is based on the principle of dipping the desired substrate into the prepared sol-gel solution at a certain speed and removing it at the same speed (Figure 1) [7]. The most used method in thin-film production is sol-gel technology. During sol-gel thin-film formation by immersion, the substrate is drawn vertically from the desired coating solution so that the precursors are concentrated on the substrate surface by a procedure that includes simultaneous drying and gravitational discharge with continuous condensation reactions [8]. The immersion method is a process applied at constant speed, controlled temperature, and atmospheric conditions. Coating thickness depends on substrate withdrawal speed, surface tension of substrate, density, and viscosity of coating solution.[9].

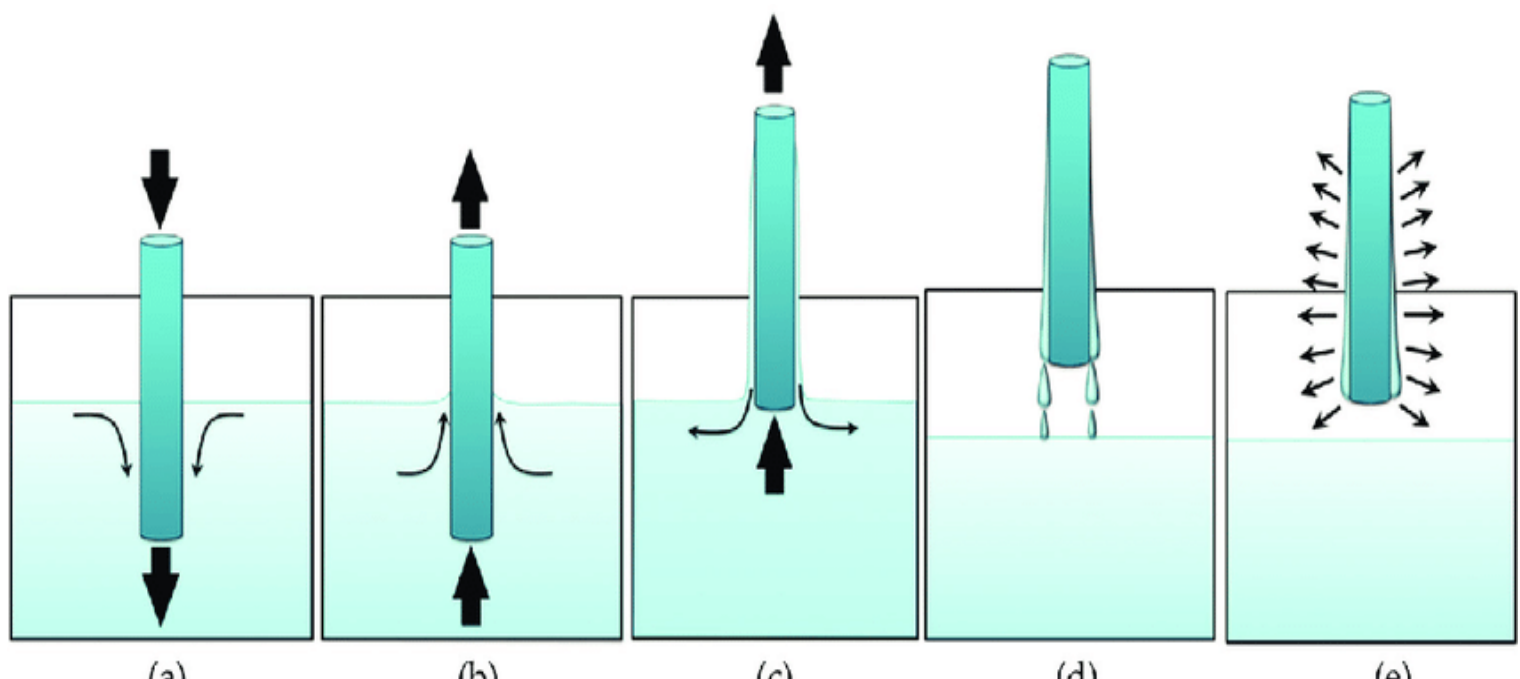

(a)

(b)

(c)

(d)

(e)

Figure 1. Dip coating steps [6].

The contact angle is one of the common approaches for measuring the wettability of a solid surface, which can be used to determine and indicate the chemical, physical properties of surfaces, and refers to the angle that occurs between a solid/liquid/gas interface at the surface of the solid [10]. The magnitude of the angle also indicates that the interaction between solid and liquid is low [11]. When the contact angle is $0^{\circ}$, the liquid spreads completely over the surface; When it is $180^{\circ}$, it does not spread at all. When the angle is over 90 degrees, the solid surface is hydrophobic; It becomes hydrophilic when the angle is below $90^{\circ}$ [12]. The size of this angle between the surfaces depends on the difference between the adhesion and cohesion forces [13]. 

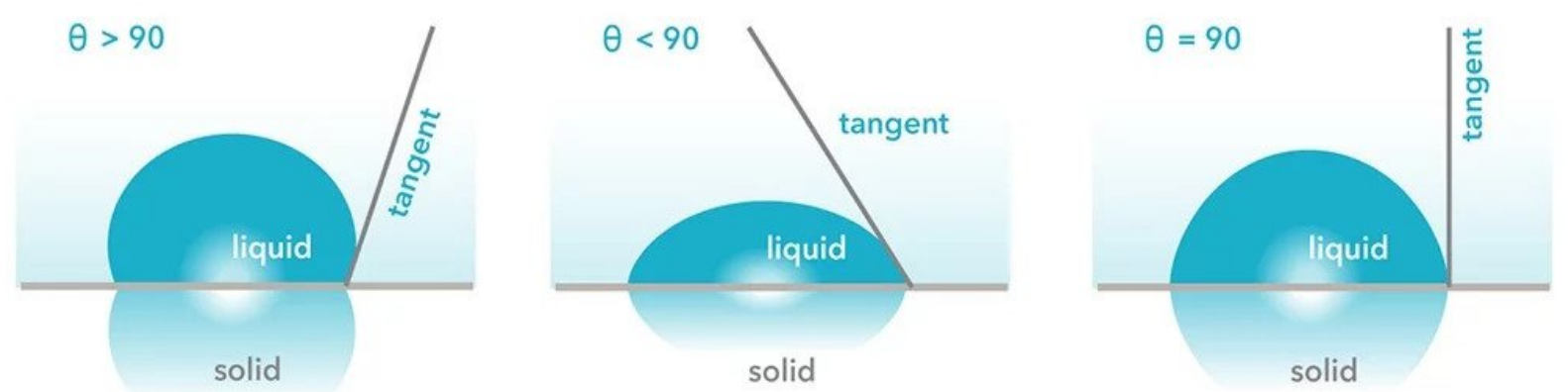

Fig 2. Different contact angles on a surface (int ref 1)

The simplest contact angle is called the constant drop-off or static contact angle. However, there are a number of fixed contact angles that exist for the surface depending on factors such as chemical homogeneity, topography, and roughness.

The wettability of the surfaces depends on the free energy of the surface and the geometric properties of the material surface [14]. In the case of water, surface wettability can be classified as hydrophobic, hydrophilic, superhydrophobic, and superhydrophilic according to the value of the contact angle [15].It has a very important place for controlling the wetting ability [16], adhesion and selective absorption, development of medical equipment, self-cleaning and anti-fogging and similar studies. Some of these applications require liquids to fully wet solid surfaces.

The term "superhydrophilic" was first used by Fujishima et al. 17]. Surfaces with contact angle less than $10^{\circ}$ with water are superhydrophilic surfaces [18]. On superhydrophilic surfaces, water spreads on a flat surface, not as droplets [19]. Stains and dirt on the surface can be easily washed off with this spreading water layer. Superhydrophilic materials have applications in many fields, including vehicle glass, window glass, microscopes, glasses, solar panel covers, electronic device screens and optical instruments, oil-water separation, self-cleaning surfaces [20,21].

\section{Material and Method}

Titanium (IV) isopropoxide (TTIP) (Sigma-Aldrich Co.), Triton X-100 (sigma), hydrochloric acid (37\% $\mathrm{HCl}$ ), phosphoric acid (Sigma H3PO4), acetone (Sigma), isopropyl alcohol (Sigma), and deionized water (DI) are used as precursors. All the reagents were used as received. The glass substrates of $1.5 \mathrm{~cm} 5 \mathrm{~cm}$ were used as substrates in all experiments. To get a uniform coating layer, the glass substrates were cleaned by the cleaning procedure described below.

For surface pre-treatment, the glass surfaces were ultrasonically cleaned with double distilled water for 10 min. Chemical cleaning procedure was carried out by soaking the glass substrates in $\mathrm{NaOH}, \mathrm{DI}, \mathrm{H} 3 \mathrm{PO} 4$, and DI for $5 \mathrm{~min}$ respectively. All glass substrates were dried at $80^{\circ} \mathrm{C}$ for $2 \mathrm{~h}$ before coating.

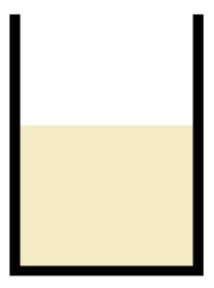

$\mathrm{NAOH}$

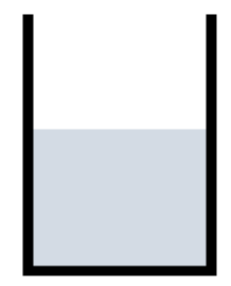

Deionize water

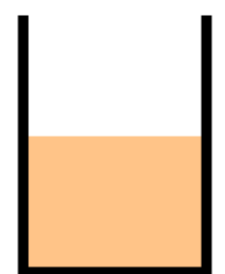

H3PO4

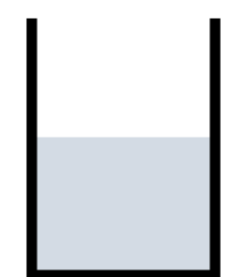

Deionize water

Fig 3. washing substrates 
TiO2 solutions were prepared by dissolving TTIP in isopropyl alcohol and DI. Sol was continuously stirred for 1 hour at room temperature and added $\mathrm{HCl}$ to adjust the $\mathrm{pH}$ of the solution. The prepared sol holds on room condition for 2 days aging process.

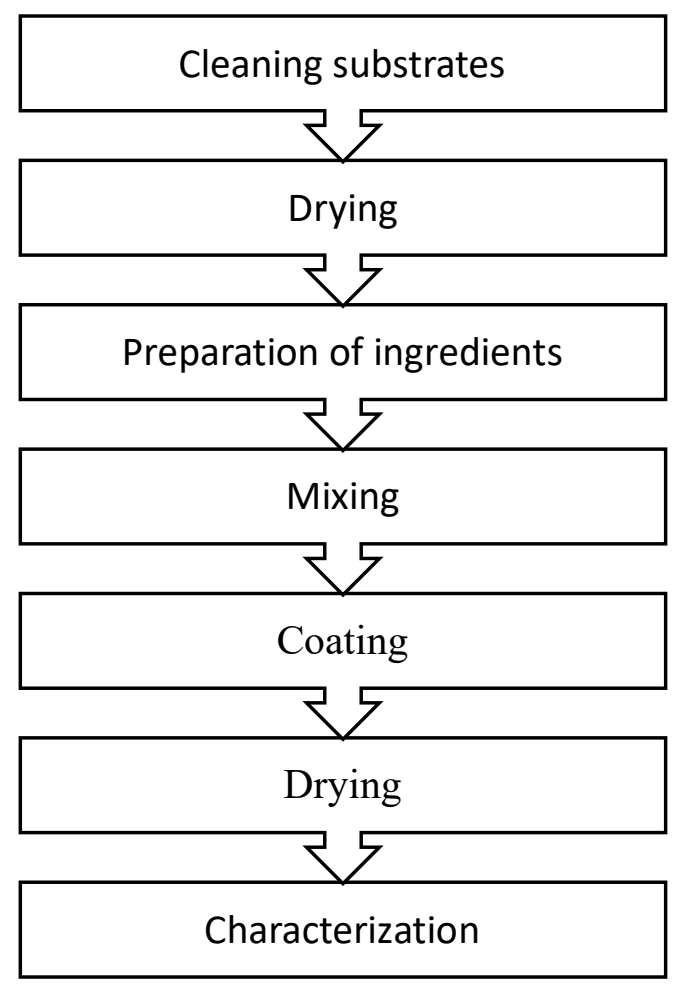

Fig 4. Flowchart of experiment

\subsection{Dip Coating}

The prepared Ti solution is placed in a Borosilicate Beaker. Glass substrates were deposited by a homemade dip-coater with heating chamber (Fig 5). Films were deposited at $10 \mathrm{~mm} . \mathrm{s}-1$ withdrawal speed at room temperatures. Then coated glasses were heated at $60^{\circ} \mathrm{C}$ for 10 minutes in the heating chamber and coated next layer. The dipping process was repeated 5 times. Finally, all coated glasses were applied to heat treatment at $450{ }^{\circ} \mathrm{C}$ for 1 hour. 


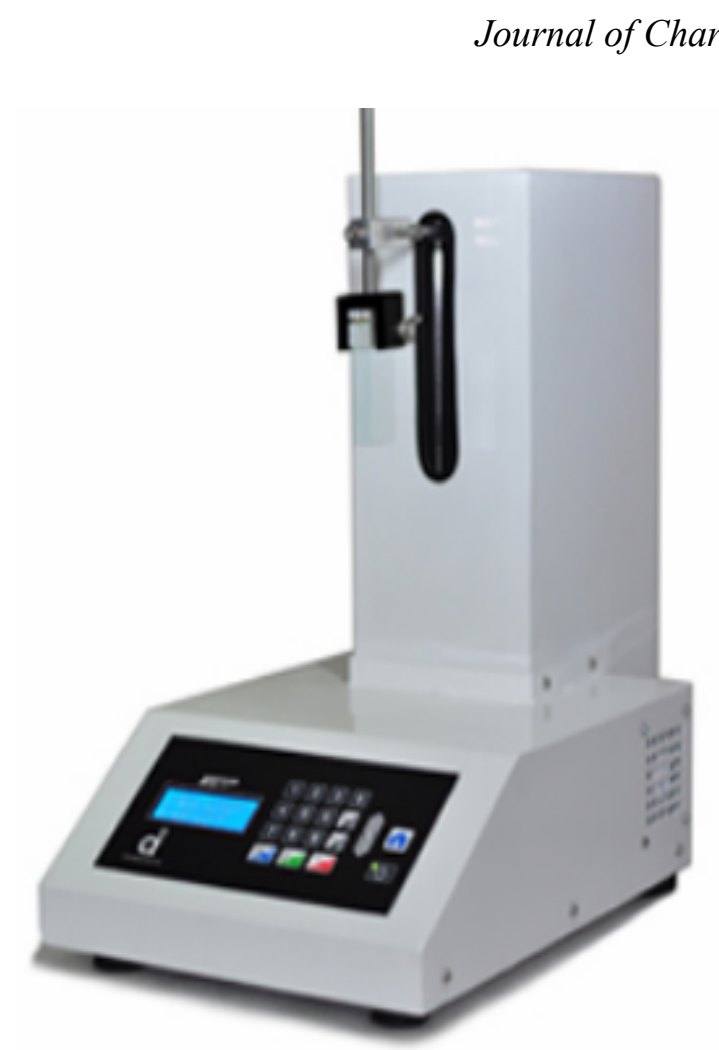

Fig 5. Home-made dip coater.

The contact angle of each sample was obtained by using the Sessile Drop technique at room temperature $\left(25 \pm 2{ }^{\circ} \mathrm{C}\right)$ using pure water with "KSV Attension Theta Lite TL 101 Optical Tensiometer" instrument (Fig 6). 2 polar (water and ethylene glycol) and 1 apolar (diiodomethane) liquids were used in contact angle measurements.

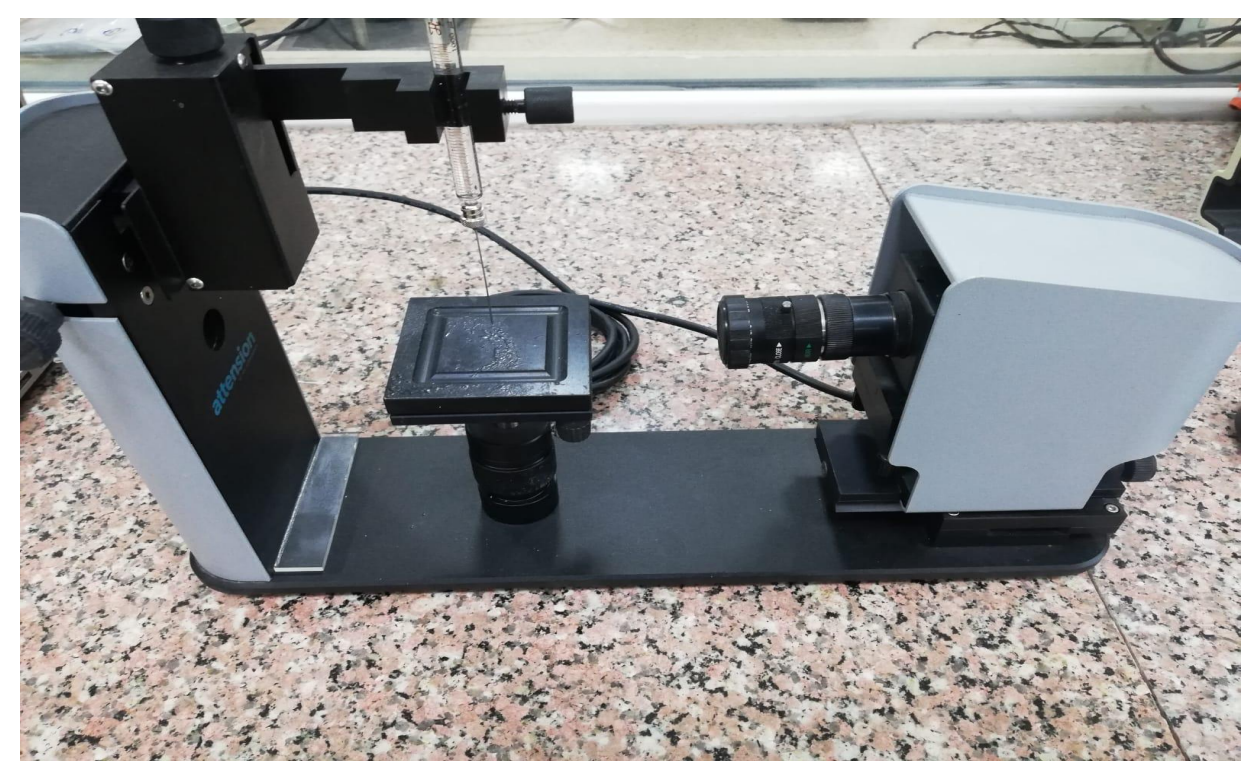

Fig 6. KSV Attension Theta Lite.

Surface and cross-section images of the coating layers were made with the Leo 1430 VP model scanning electron microscope (SEM). A clear view could not be obtained from the cross-section in 1 and 2 layer coatings. 


\section{Journal of Characterization}

Thin films were characterized by BYK-Gardner haze gard dual Light Transmittance / Haze Meter, and Konica Minolta Multi Gloss 268 Gloss Meter (Fig.7). The Haze-Gard Dual measures Total Transmittance and Haze according to two international standards: ISO 13468 and ASTM D1003. The Gloss meter is a portable and compact gloss meter consisting of three measuring angles $\left(20^{\circ}, 60^{\circ}\right.$ and $\left.85^{\circ}\right)$, each in accordance with DIN 67 530, ISO 2813, ISO 7668 ASTM D 523, BS 3900, BS 6161, and JIS Z 8741 standards.
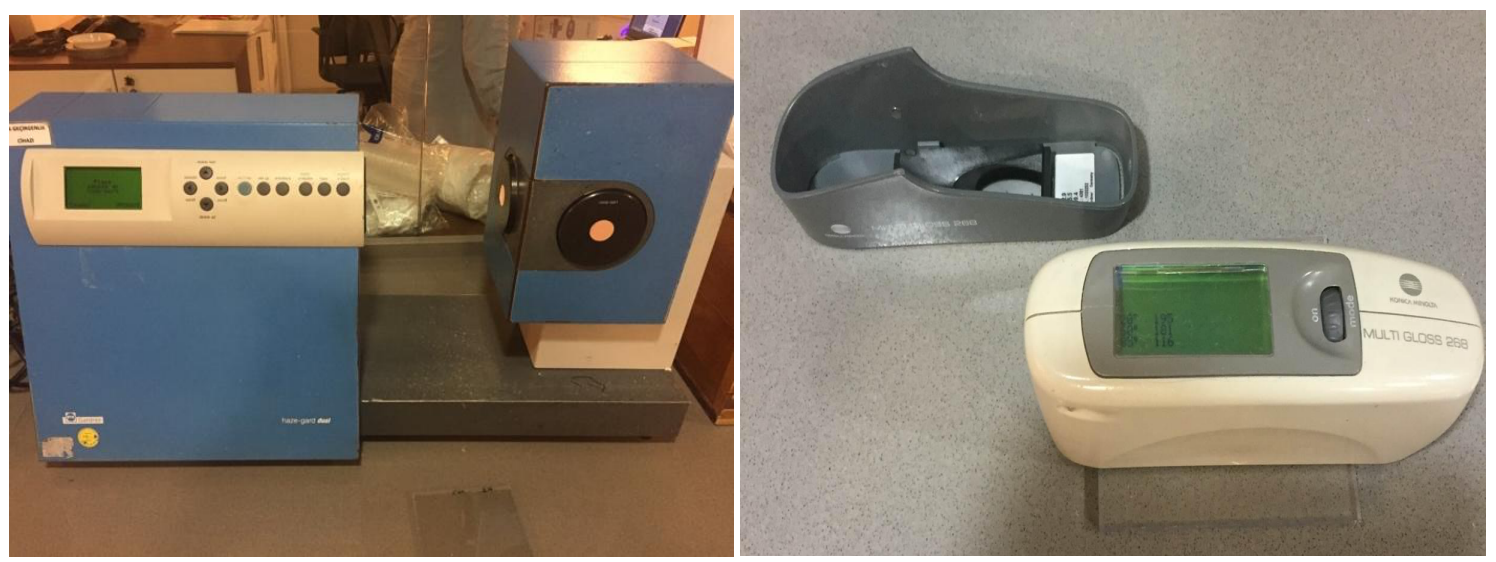

Fig. 7 Light Transmittance /Haze Meter and Gloss Meter

\section{Results and Discussion}

\subsection{Contact angle Measurements}

Tablo 1. Contact angle results

\begin{tabular}{|c|c|c|c|c|c|c|}
\hline & Water & $\mathrm{CA}\left({ }^{\circ}\right)$ & Ethylene glycol & $\mathrm{CA}\left(\left(^{\circ}\right)\right.$ & Diiodo methane & $\mathrm{CA}\left(\left(^{\circ}\right)\right.$ \\
\hline 1. Layer & & 50.28 & & 50.97 & & 48.27 \\
\hline 2. Layers & & 54.14 & & 51.39 & & 50.17 \\
\hline 3. Layers & & 64.62 & & 57.70 & & 50.29 \\
\hline 4. Layers & & 75.43 & & 59.58 & & 53.41 \\
\hline 5. Layers & & 80.59 & & 66.22 & & 53.77 \\
\hline
\end{tabular}




\section{Journal of Characterization}

It can be seen from Table 1, as the number of layers increased, the contact angle value increased for all liquids. However, the surface showed hydrophilic character in all coating layers. The increase in the number of layers was less effective for apolar liquid than for a polar liquid. The lowest contact angle value is 48.27 degrees in 1 layer for diiodomethane. The highest contact angle value is 80,59 degrees in 5 layers for water.

Micro cracks occurring in the coatings appear in the surface images. film thicknesses are $804.7 \mathrm{~nm}, 679.6$ $\mathrm{nm}$, and $772.1 \mathrm{~nm}$ for 3,4 , and 5 coatings, respectively. As expected, the increase in the number of layers resulted in an increase in film thickness.

Table 2. SEM images of layers

\begin{tabular}{|l|l|l|l|l|l|}
\hline & 1. Layer & 2. Layers & 3. Layers & 4. Layers & 5. Layers \\
\hline Surface & NA & NA & & & \\
\hline $\begin{array}{l}\text { Cross } \\
\text { section }\end{array}$ & NA & NA & & & \\
\hline
\end{tabular}

Table 2. Physical properties of layers

\begin{tabular}{|l|l|l|l|l|l|}
\hline Properties & 1. Layer & 2. Layers & 3. Layers & 4. Layers & 5. Layers \\
\hline$\%$ Transmittance & 91 & 90 & 90 & 89 & 88 \\
\hline$\%$ Haze & 2,54 & 3,87 & 5,46 & 6,88 & 9,10 \\
\hline Gloss $\left(60^{\circ}\right)$ & 174 & 156 & 148 & 126 & 108 \\
\hline
\end{tabular}

SEM-EDX data of the coating layer are given in Figure 8. 


\section{Journal of Characterization}
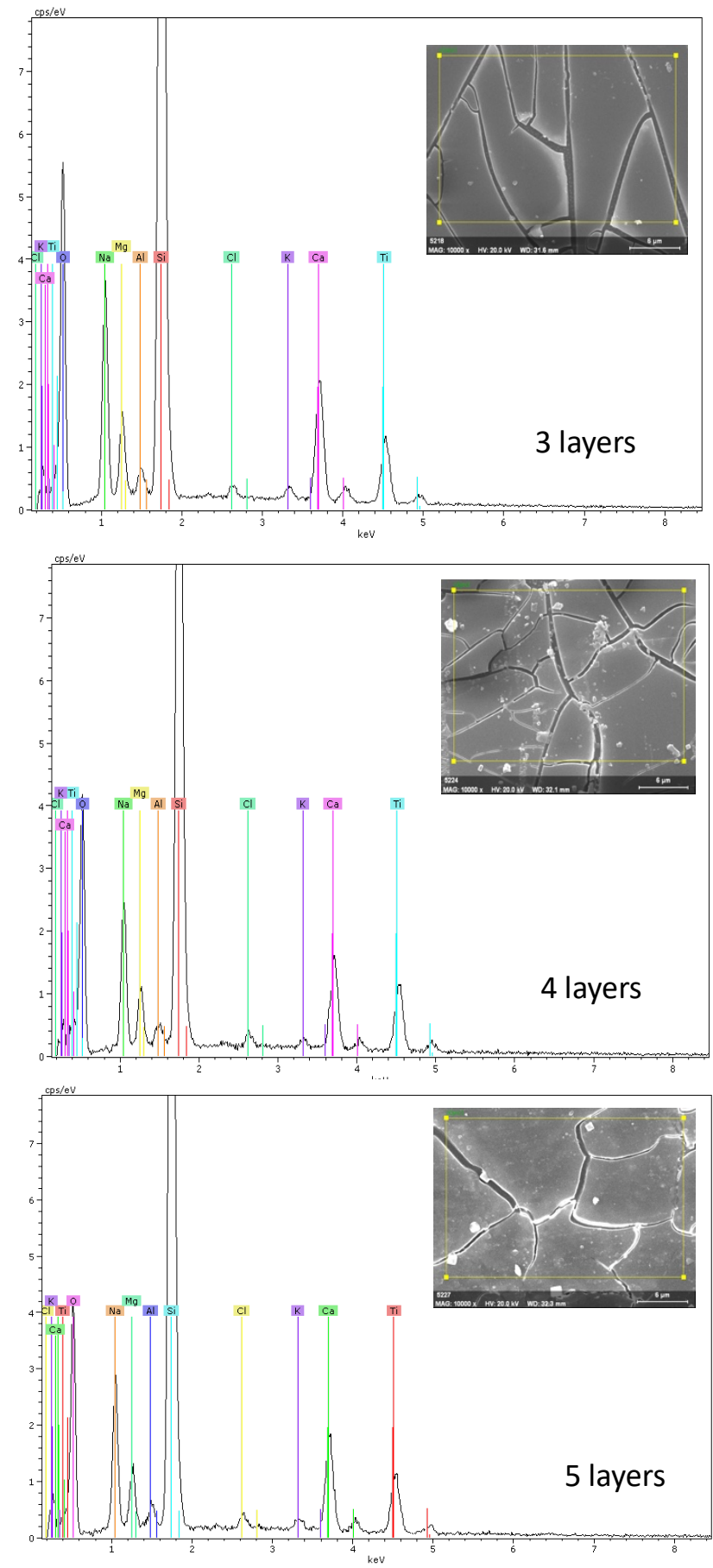

\begin{tabular}{|c|c|c|c|}
\hline \multirow[t]{2}{*}{ Element } & \multicolumn{3}{|c|}{ Atom. C [wt.-\%] } \\
\hline & 3 layers & 4 layers & 5 layers \\
\hline Oxygen & 57.03 & 64.17 & 65.06 \\
\hline Sodium & 7.87 & 6.29 & 6.14 \\
\hline Magnesium & 2.41 & 1.76 & 1.65 \\
\hline Aluminium & 0.75 & 0.42 & 0.42 \\
\hline Silicon & 26.30 & 21.97 & 21.18 \\
\hline Chlorine & 0.53 & 0.25 & 0.19 \\
\hline Potassium & 0.45 & 0.28 & 0.21 \\
\hline Calcium & 2.83 & 2.60 & 2.52 \\
\hline Titanium & 1.82 & 2.26 & 2.63 \\
\hline
\end{tabular}

Fig. 8 SEM-EDX results 


\section{Journal of Characterization}

From the EDX data in Figure 8, non-titanium elements come from the base glass. The presence of the element titanium indicates that the coating has taken place. As can be seen from Figure 8, with the increase in the number of layers, the percentage by weight of the titanium atom also increases. This is a sign of how sensitive the coating has been made.

Figure 9 shows the elemental map of the coating surface. The distribution of orange-colored titanium and green-colored oxygen atoms can be seen on the surface.
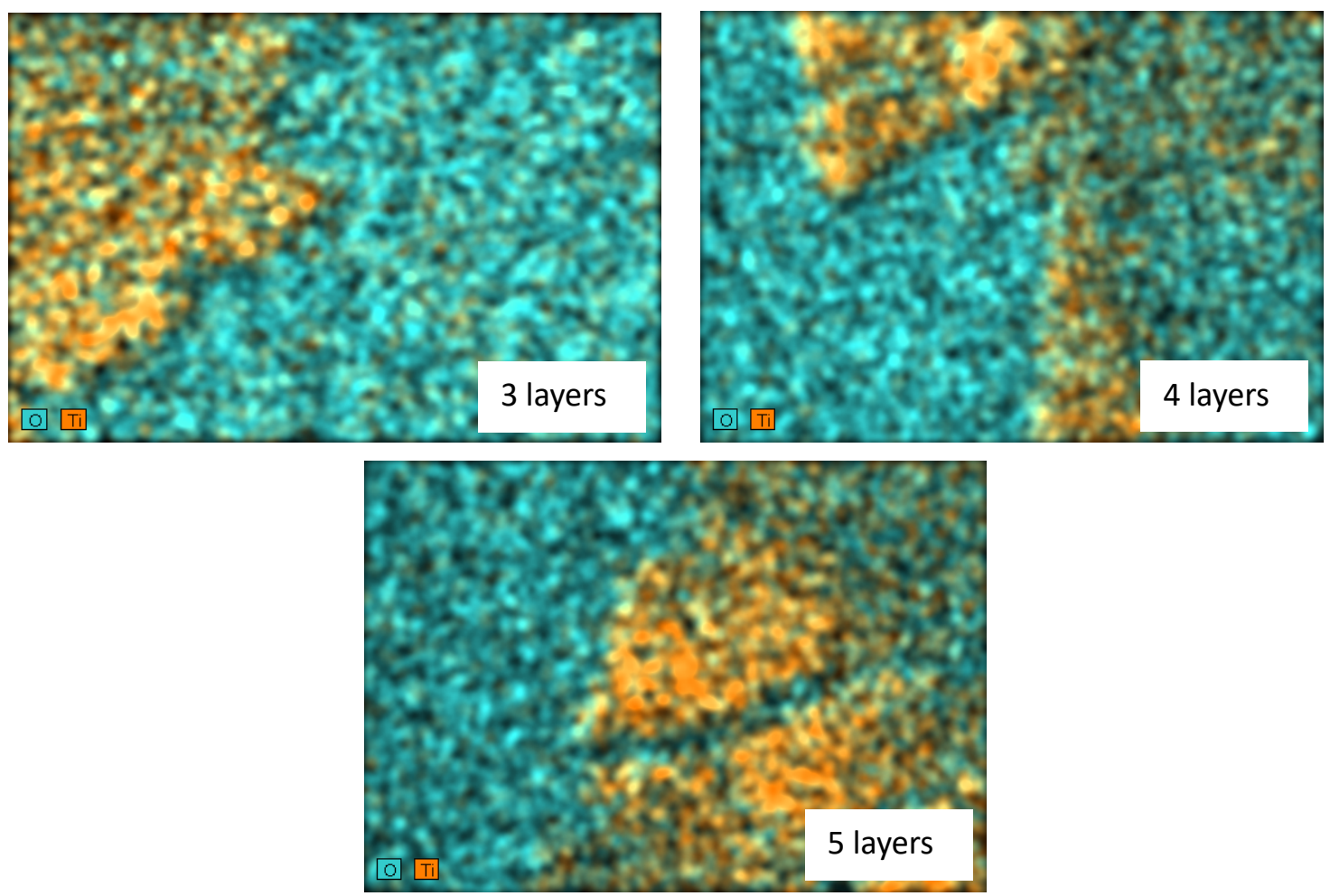

Figure 9 Colorized photograph of selected area of coatings

\section{Conclusions and Recommendations}

In this study, hydrophilic coating was obtained by sol-gel method. The effects of the solvent type and the number of coating layers on the contact angle in the coating on glass have been revealed.

As the number of coating layers increased, the percentage of light transmittance and gloss value decreased. However, the haze value increased.

All coated samples were hydrophilic. The increase in the number of coating layers caused an increase in the contact angle.

Depending on the solvent type, the contact angle value is in the form of water $>$ ethyleneglycol $>$ diiodomethane from larger to smaller.

\section{Acknowledge}

I would like to thank Afyon Kocatepe University Institute of Science and Scientific Research Projects Coordination Unit (BAPK) for the support of the project numbered 20.FEN.BILL.32. 


\section{Journal of Characterization}

\section{References}

1.Toygun, Ş., Köneçoğlu, G., \& Kalpakli, Y. (2013). General Principles Of Sol-Gel. Sigma: Journal of Engineering \& Natural Sciences/Mühendislik ve Fen Bilimleri Dergisi, 31(4).

2.Sangchay, W. (2016). The self-cleaning and photocatalytic properties of TiO2 doped with $\mathrm{SnO} 2$ thin films preparation by sol-gel method. Energy Procedia, 89, 170-176.

3.Akpan, U. G., \& Hameed, B. H. (2010). The advancements in sol-gel method of doped-TiO2 photocatalysts. Applied Catalysis A: General, 375(1), 1-11.

4.Keszei, S. J., Pekker, P., Fehér, C., Balogh, S., Jakab, M., Nagy, L., \& Skoda-Földes, R. (2020). Application of sol-gel methods to obtain silica materials decorated with ferrocenyl-ureidopyrimidine moieties. Preparation of hollow spheres and modification of a carbon electrode. Microporous and Mesoporous Materials, 308.

5. Wang, Y. T., Zhang, X. T., Xu, J. B., Shen, Y., Wang, C. A., Li, F. W., ... \& Shen, R. Q. (2020). Fabrication and characterization of Al- $\mathrm{CuO}$ nanocomposites prepared by sol-gel method. Defence Technology. 110380.

6. Otitoju, T. A., Ahmad, A. L., \& Ooi, B. S. (2017). Superhydrophilic (superwetting) surfaces: A review on fabrication and application. Journal of industrial and engineering chemistry, 47, 19-40

7. Göksu E. (2016). Sol-Jel Yöntemiyle Antibakteriyel İnce Film Kaplanması/Yüksek Lisans Tezi,Afyon Kocatepe Üniversitesi Fen Bilimleri Enstitüsü, Afyonkarahisar

8. Brinker, C. J., Frye, G. C., Hurd, A. J., \& Ashley, C. S. (1991). Fundamentals of sol-gel dip coating. Thin solid films, 201(1), 97-108.

9. Kurtulus, C., Kurtulus, R., Surface Modification of Anhydrous Borax with Stearic Acid by Wet Coating Method, Journal of Characterization, Vol 1 (1), 1-9, 2021.

10. Adam, N. K. (1964). The chemical structure of solid surfaces as deduced from contact angles

11. Drelich, J., \& Chibowski, E. (2010). Superhydrophilic and superwetting surfaces: definition and mechanisms of control. Langmuir, 26(24), 18621-18623.

12. Marmur, A., Della Volpe, C., Siboni, S., Amirfazli, A., \& Drelich, J. W. (2017). Contact angles and wettability: towards common and accurate terminology. Surface Innovations, 5(1), 3-8.

13.Song, J. W., \& Fan, L. W. (2020). Temperature dependence of the contact angle of water: A review of research progress, theoretical understanding, and implications for boiling heat transfer. Advances in Colloid and Interface Science, 102339.

14. R. N. Wenzel, "Resistance of solid surfaces to wetting by water," Industrial Engineering Chemistry, vol. 28, pp. 988-994, 1936.

15. Yuan, Y., \& Lee, T. R. (2013). Contact angle and wetting properties. In Surface science techniques (pp. 3-34). Springer, Berlin, Heidelberg.

16. J. Fang, A. Kelarakis, L. Estevez, Y. Wang, R. Rodriguez ve E. P. Giannelis, "Superhydrophilic and solvent resistant coatings on polypropylene fabrics by a simple deposition process," Journal of Materials Chemistry, vol. 20, pp. 1651-1653, 2010.

17.A. Fujishima, T. N. Rao ve D. A. Tryk, "Titanium dioxide photocatalysis," Journal of Photochemistry and Photobiology C: Photochemistry Reviews, vol. 1, pp. 1-21, 2000. 


\section{Journal of Characterization}

18.Çiğil, A. B., Kandirmaz, E. A., Birtane, H., \& Kahraman, M. V. Yüksek Hidrofilik Polietilen İmin Kaplamaların Hazırlanması Ve Karakterizasyonu. Düzce Üniversitesi Bilim ve Teknoloji Dergisi, 7(3), 973-984.

19.J. Drelich, E. Chibowski, D. D. Mengb ve K. Terpilowskic, "Hydrophilic and superhydrophilic surfaces and materials," Soft Matter, vol. 7, no. 21, pp. 9804-9828, 2011.

20.Zhang, H., Guo, G., Liu, L., Tao, F., Ren, J., \& Zheng, L. (2019). Durable, water-cleanable, superhydrophilic coatings for oil/water separation under harsh conditions. Journal of Saudi Chemical Society, 23(8), 1007-1015.

21. Adachi, T., Latthe, S. S., Gosavi, S. W., Roy, N., Suzuki, N., Ikari, H., \& Terashima, C. (2018). Photocatalytic, superhydrophilic, self-cleaning $\mathrm{TiO} 2$ coating on cheap, light-weight, flexible polycarbonate substrates. Applied Surface Science, 458, 917-923.

İnt ref 1 https://www.nanoscience.com/techniques/tensiometry/ 